Article

\title{
Healing Space: The Synaesthetic Quality of Church Architecture
}

\author{
Bert Daelemans
}

Department of Dogmatic and Fundamental Theology, Faculty of Theology, Comillas Pontifical University, 28015 Madrid, Spain; bdaelemans@comillas.edu

Received: 12 November 2020; Accepted: 23 November 2020; Published: 26 November 2020

check for updates

\begin{abstract}
There is a growing literature on the healing effects of buildings designed for healthcare, but publications that insist on this spiritual and healing dimension in church architecture are rare. Contemporary ecclesial buildings are often rightly criticized for their cold and soulless emptiness. However, through the analysis of four emblematic case studies, this article aims to lay bare an essential dimension of architecture that is often overlooked, a multisensory and synaesthetic dimension that engages our body even before we become aware of it. Hence, this article builds upon the recurrent plea of spatial theorists, philosophers, and architects for synaesthetic space as a reaction to a dominant ocularcentric environment. Surprisingly, contemporary church architecture seems rather propitious to deploy this inherently religious dimension that is at once healing and spiritual in a new sense, which is especially needed nowadays.
\end{abstract}

Keywords: bodily senses; body; built environment; church building; nature; sacred architecture; spirituality; synaesthesy; theology of architecture

\section{Introduction: Synaesthetic Space}

In a famous 1984 study, one of the now most influential researchers in healthcare architectural design, Roger S. Ulrich, measured for the first time how a hospital 'room with a view' could considerably reduce the time of recovery from surgery. Patients looking out at a row of trees cured faster than similar patients seeing only a brick wall (Ulrich 1984). Years later, Dr. Esther M. Sternberg, whilst admitting that "we don't yet fully understand all the ways in which windows could affect healing," is convinced that place has an effect on the healing process: "If you are living in dark, cramped, crowded quarters where noise is constant, you will be stressed. If you are isolated, far from friends and family, you will be stressed. In such cases your immune system is burdened and the healing process slows" (Sternberg 2009, pp. 20-21).

This article points at a multisensory and spiritual dimension of our built environment that is often still overlooked, but which the current ecological turn and the global context of COVID-19 have again brought to the fore. There is a growing literature on the healing effects of gardens and buildings designed for healthcare, based upon empirical data (Cooper Marcus and Barnes 1999; Handy et al. 2002; Macmillan 2004; Ulrich et al. 2004; Ulrich 2006; Codinhoto et al. 2009; Tzortzopoulos et al. 2009; Huisman et al. 2012; Tsekleves and Cooper 2016; Sigrist 2019). Recently, a volume of the journal Spiritual Care, intended for the multi-disciplinary exchange between researchers and workers in healthcare and spiritual care, has been dedicated to the topic of "spiritual spaces" (Spirituelle Räume), although within the context of healthcare architecture (Frick and Maidl 2019). Still, publications that insist on this healing dimension in church architecture are rare (Böhme 2006). On the contrary, contemporary church architecture is often attacked for the cold and impersonal atmosphere it seems doomed to create (Rose 2001; Doorly 2007; McNamara 2009), although other voices claim that its inherent (albeit 
ineffable and anonymous) spirituality makes religious buildings especially propitious to express these synaesthetic qualities (Dupré 2001; Frampton 2002; Heathcote and Moffat 2007; Bergmann 2009).

Hence, after briefly pointing out that healing and place belong together, drawing upon the work of one interlocutor who is specialized in the field of healthcare (Sternberg 2009), this article engages in the discussion with spatial theorists (Lefebvre [1974] 1991; Tuan 1977; de Certeau [1980] 1990; Casey 1993; Soja 1996), philosophers (Foucault [1984] 1986; Böhme 1995; Kidder 1999; Marion 2010; Han 2015), psychologists (Evans and McCoy 1998), and architects (Day [1990] 2004; Holl 1994; Pallasmaa 1996; Zumthor 2010) in order to point out the spiritual and healing qualities of what I have coined "synaesthetic space" (Daelemans 2015a). As this concerns an unconscious and invisible dimension of our experience of place, let us define "synaesthetic space" from the start as the specific atmosphere or genius loci that comes to the fore when a human being interacts with a place by dwelling in it, walking through it, or simply being in it: space is "relational" (Löw 2001, p. 224; Wüthrich 2010). "Synaesthetic space" is always a unique genius loci of a certain place at a certain time for a certain person, for which it is not easy to grasp or speak about (Norberg-Schulz 1980). This has to do with the way a building engages with nature, which can be done in different ways, such as "abstracting" nature (Goldberger 2010, p. 228) or opening a window to the landscape (Daelemans 2015b).

As such, in this article, it is merely my aim to "point out" this dimension, corroborating my own synaesthetic experience of four case studies with that of others found in the literature. In the description of these case studies, it is not my intention to lay universal claims upon the experience of these buildings, which is always a highly personal experience. Hence, what will be said of these case studies in particular might not be true for everyone in the same degree. Nevertheless, these four case studies (there could have been others) all seem to provoke a high density of synaesthetic space, only because of the way they engage the body, obliging people to move around and get lost, as it were, or because of the texture of its architectural skin. All in all, this article intends to lay bare an intuitive dimension that is difficult to measure scientifically. There is little existing evidence on how specific design features impact human health, but the aim of this article is to provoke further research following this intuition. Awareness and better understanding of this synaesthetic dimension may enable both designers and users to create and maintain healthy environments.

From the start, "healing", "spiritual", and "synaesthetic" should be understood in a broad sense, although they all address the body (Brichetti 2019, p. 3). Healing, in a spiritual context, has to do with wholeness, and spirituality is broader than religiosity (Frick 2007, p. 12). I would claim that, if a certain place gives a person the awareness of self and of her being embodied and embedded in nature, this is already (a step towards, and thus) spiritual healing. Visitors of church buildings are not patients, but it can be assumed that all carry wounds that need healing, peace, recovery, reconciliation, or restoration in some sense. That place and space play a role in healing can be corroborated by researchers in healthcare (Sternberg 2009; Uzarewicz 2013; Wüthrich 2019). That buildings explicitly made for spiritual activities have a role to play in spiritual healing is the topic of this article. The intuition upon which this study is built, and that gradually will be corroborated with the literature and with field work, can be formulated as such: there is a way in which architecture addresses the body that is healing, and which has to do with the "synaesthetic space" that comes to the fore in the interaction and spatial practice of human beings. I deem it sufficient that the relationship between healing and space has been pointed out by researchers in healthcare, so it is my intention to build further upon this claim by including also the spiritual dimension in healing (Brichetti 2019, p. 3).

Acknowledging the lack of empirical evidence in this field, the psychologists Evans and Mitchell McCoy nevertheless defined five architectural dimensions as being linked to stress and that, therefore, potentially could affect human health: stimulation, coherence, affordance, control, and restoration (Evans and McCoy 1998, p. 92). Stimulation has to do with "intensity, variety, complexity, mystery and novelty" (Evans and McCoy 1998, p. 85). The four case studies that I have chosen, as we will see, excel in this matter. According to these authors, lack of stimulation leads to boredom and an overabundance of stimulation causes distraction, disorientation, and overload when a strong unifying 
theme or coherence and comprehensibility is lacking. Indeed, "people like small amounts of change but do not adapt well to large amounts of variation" (Evans and McCoy 1998, p. 86), which therefore must be balanced with familiarity and routine. Mystery, for them, indicates "the promise of further information with continued exploration" (Evans and McCoy 1998, p. 86).

Affordance means that we can understand correctly the functional properties of a space; misaffordance is often the cause of accidents. By control, the authors mean the ability to alter the space, that is, how flexible a space is for being adapted and owned by its users: "Insufficient spatial resources, inflexible spatial arrangements, and lack of climatic or lighting controls all threaten individual needs to effectively interact with interior space" (Evans and McCoy 1998, p. 88). Finally, with restorative qualities, the authors indicate the therapeutical function of design elements to reduce and attenuate stress, and they especially name "retreat, fascination, and exposure to nature. Certain types of settings such as religious sanctuaries, hospitals and other therapeutic facilities are explicitly designed with restorative intent. Such settings may uplift the human spirit and promote healing. [... ] Reflective activities in particular demand a minimum of distraction and some degree of isolation. [ ... ] Direct contact with natural elements as well as views of nature provide restoration" (Evans and McCoy 1998, p. 91).

Through the analysis of recent case studies that emblematically excel in those 'haptic' (Hall 1969; Pallasmaa 1996) qualities, this contribution will focus especially and apologetically on contemporary church architecture as a plea for a spiritual dimension that is not limited to its religious function, but can and must be located, as it were, in its 'skin' and 'atmosphere'. Therefore, I will not engage in the liturgical aspect of these buildings, but rather interrogate them on their spiritual claim before any religious or liturgical activity takes place. The way that the synaesthetic dimension is been engaged religiously by a liturgical community 'in action' has been described elsewhere (Daelemans 2015a, pp. 251-314). Unfortunately, too often in the existing literature, the liturgical assessment of religious buildings fails to acknowledge its synaesthetic qualities, and thus fails to bring them into play. To lay bare the idea that the theological assessment of religious buildings is not limited to their liturgical function has been an underlying aim of this study. The liturgical aspects, at least for the Roman Catholic liturgy, are treated elsewhere (Schloeder 1998; López Arias 2018).

All in all, this article aims to contribute to the renewed acknowledgment of an often ignored spiritual and sacramental dimension of life that has to do with our ways of being embodied and 'embedded' in the (natural) environment (Schmemann 1973; Daelemans 2015b, 2015c).

\section{The Healing Effect of Synaesthetic Space}

"Perhaps the most important thing a window does is provide a portal [ ... ] allowing a patient to step into a space of meditation-a reverie that brings not just distraction but relief. And relief could bring healing, through all those beneficial chemicals that flow from the brain through the body and change illness into wellness". (Sternberg 2009, pp. 9-10)

Dr Sternberg expresses herself in multisensory terms that I call synaesthetic in order to emphasize its extraordinary simultaneous convergence: "Our sense of place is created through what we see and feel and smell and hear-through all our senses. It is created and re-created in memory each time we experience and re-experience the place. Emotions, both good and bad, become attached to a place [... ]. A place can trigger unhappy memories or bad habits without our realizing it, and cause us to spiral down into drug addiction or despair" (Sternberg 2009, pp. 21, 290).

What brings healing and space together is that both imply movement: "Just as healing is a constant process, so is sense of place" (Sternberg 2009, p. 15). Healing, more than curing, indicates a sense of wholeness, of feeling and becoming whole, even when one does not get cured. Healing "goes beyond the mere absence of disease and incorporates sustenance of the emotions as an essential part" (Sternberg 2009, pp. 293-94). Sternberg wonders if the healing effect of windows has to do with their power to distract patients from their disease or rather with their providing natural light, color, air, shapes, sounds, smells, movement, life, and awareness of day-and-night rhythms. 
Although, in my view, in general she focuses too much on objects that can be seen and not directly on the healing expansion of the space itself-which is visually broadened, enlarged by the window - she suggests, based on neuroscientific research, that movement in vision (far and near, in and out, up and down) has a healing effect: "We are constantly scanning the horizon for things that stand out" (Sternberg 2009, p. 32; Aguirre et al. 1998; Epstein et al. 2007). In my view, a window does not just provide an outlook but sensibly enlarges living space-and this is a healing effect of the space itself and not merely of an object one sees (a beautiful tree, for instance).

Even though Sternberg does not use the concept of synaesthetic space, she recognizes that our brain forms an integral sense of place out of different sensory inputs. She acknowledges that "the sense of touch is also connected to our sense of sight. When you look at a plank of wood, you can tell whether it is likely to fell rough or smooth" (Sternberg 2009, p. 93). When moving, our brains register more than visual landmarks: proprioceptive cues from our inner ear and our muscles explain why a driver remembers a route "much faster and much better than when just viewing it from the passenger seat" (Sternberg 2009, p. 138).

Natural light has been proven to improve the mood, health, and immune systems of shoppers, office workers, and hospital residents. Someone who is ill and recovering is craving for peace and quiet, but a hospital usually offers only loud and strange noises. Noise is one of the biggest stressors, especially noise that comes from an unseen source. Sternberg recalls a Swedish hospital where sound-absorbing tiles reduced noise levels substantially, which improved, not only health outcomes and the frequency of rehospitalizations, but also staff's satisfaction and home sleep quality.

Quiet places are healing because they make us aware of (life within) the place by putting us in touch with nature through awareness of "the tiny sounds that are usually drowned out by background noise": even when closing your eyes, "you can tell the seasons or the time of day" (Sternberg 2009, p. 53). Space is only healing when it is quiet-not empty, not the frightening silence of isolation, but quiet, allowing the tiny sounds to do their gentle, soothing, and healing cure.

What is true for healthcare architecture can be transposed to our environment in general. In the end, we human beings are embedded in nature, and nature is an essential partner in the holistic process of healing. Some architects have intuited this very early on. The great architects Frank Lloyd Wright, Richard Neutra, Alvar Aalto, and Peter Zumthor should be named, of course, but also Welsh builder Christopher Day: his Places of the Soul (1990) remains a classic in pointing out the healing and unseen effects of architecture.

Our immediate environment affects us: "Without consciously looking at them, we breathe in our surroundings with all our senses" (Day [1990] 2004, p. 4). Indeed, it does not matter "how nice a place looks if it smells of bad drains" (Day [1990] 2004, p. 5). Buildings can make us ill without our realizing it.

Places can also contribute to healing; Sternberg recalls a widow who found healing in the restaurant where she had spent long evenings with her husband. Furthermore, she argues that it was "the light and beauty and spiritual aura of the place" of Assisi that had meant a breakthrough for the immunologist Jonas Salk in discovering his polio vaccine. This experience led him eventually to create the Salk Institute, intended to be an inspirational place for the research of how architecture enriches human experience (Sternberg 2009, pp. 16, 21). Already, the Romans spoke in this sense of genius loci, a certain 'spirit', energy, or character at certain (natural) places, which buildings could highlight and complement (Norberg-Schulz 1980).

In short, healing and place belong together. Indeed, as doctors and nursing staff would know, a sudden change in the awareness of our surroundings is often the first sign that healing has begun (Sternberg 2009, p. 1). In contrast, during the early stages of a disease, we are acutely sensitive to internal signs from our body and lose interest in anything beyond. Even our place memory is impaired when we are ill, which implies that navigation through the hospital (often an intimidating and frightening environment) becomes a stressful experience. 
Significantly for healthcare facilities, Sternberg dwells upon the type of imaginative experience that places such as Disneyland and Frank Gehry's buildings offer because they are at the same time comfortable and exciting, surprising and reassuring: "They skillfully change your mood [ ... ] without saying a word." You never know what to expect, and this might cause anxiety but could also trigger curiosity. Therefore, it comes as no surprise that Charles Jencks described Gehry as "committed to a notion of an architecture that relates to healing" (Sternberg 2009, pp. 136, 166).

Similarly, the following, delightful description of Venice reveals our basic human need for what the French philosopher Michel Foucault has called "heterotopias" or counter-places, which shed light upon what ordinary places lack (Foucault [1984] 1986):

"Venice changed for me the nature of light. Light was beautiful everywhere, but only in Venice did it complete itself fully. [ ... ] The city looked as though a troupe of organ grinders and manic chess players had designed it for the praise of glassblowers. Its celebration of pure whimsy made it a playground and a conundrum, a place where decadence had both a field day and a day off. It always made me wish I was a flashier, less serious man". (Conroy 1995, pp. 40-41)

\section{Discussion: Synaesthetic Space versus Ocularcentric Buildings}

"There are small and large, impressive and important buildings or complexes that dwarf me, that oppress me, that exclude or rebuff me. But there are also buildings or ensembles of buildings, both small ones and monumental ones, that make me feel good, that make me look good, that give me a sense of dignity and freedom, that make me want to stay awhile and that I enjoy using". (Zumthor 2010, p. 86)

Pritzker laureate Peter Zumthor is widely known for the experiential quality of his buildings. This is due to his choice of texture and matter, with which he engages first and foremost our skin, and reveals how architecture is indeed 'archi-texture'. This patient, contemplative, and nearly monastic attention to the sensuous qualities of architectural skin proceeds from his own experience of the contrasting effect of buildings, as shown in the quote above.

Buildings have a multisensory effect upon us that cannot be reduced to two dimensions. When entering a building, the first reality that one encounters is not an idea addressed to the mind, a sign that has to be deciphered, or an image addressed to vision, but rather an atmosphere or 'space' that immediately engulfs our embodied beings and makes us aware of being embodied, preliminary to thought and consciousness. "Space" has been defined in different ways: as the abstract and undifferentiated space of "sites" or "locations" that can be transformed into meaningful "places" (Tuan 1977; Casey 1993) and, in the sense I will adopt here, as what comes about when a site, location, or place is "practiced" by living bodies (de Certeau [1980] 1990, p. 173; Lefebvre [1974] 1991; Löw 2001, p. 224; Beuttler 2010; Wüthrich 2015). The human body is engaged with more than one sense as a living, sensing, and spiritual whole, and "space" cannot be reduced to two-dimensional space, to what we see. For defining this mysterious "space" or "atmosphere" (Böhme 1995; Beyrich 2011) that comes about, I prefer the term syn-aesthetic to multisensory because it holds the senses together (Daelemans 2015a, pp. 161-202). Gaston Bachelard spoke of the "polyphony of the senses" (Bachelard 1971, p. 6).

The founding father of spatial theory, the French Marxist thinker Henri Lefebvre, pleaded for a recognition of what he called in this sense "social" or "lived space", which is that which is "produced" when a society enacts "physical" or "perceived space" (Lefebvre [1974] 1991, p. 73). He pointed out that we usually reduce space to "conceived" or "mental space", as if space were the two-dimensional, Cartesian "representation of space" merely present in minds and on maps: "This is the dominant space in any society" that tends towards a system of verbal signs that simply could be deciphered (Lefebvre [1974] 1991, pp. 38-39). In fact, this "mental space" is only a virtual decoction of real space, 
flattened to an illusionary transparency that is unaware of the invisible, imaginary spaces that are also part of space (Soja 1996).

Lefebvre famously broadened and enriched mental space to his triad of perceived, conceived, and lived space. Firstly, he spoke of the day-to-day practice of a place, bringing to the fore perceived space: "Anyone knows what is meant when we speak of a 'room' in an apartment, the 'corner' of the street, a 'marketplace', a shopping or cultural 'centre', a public 'place', and so on. These terms of everyday discourse [ ... ] correspond to a specific use of that space, and hence to a spatial practice that they express and constitute" (Lefebvre [1974] 1991, p. 16). He compared spatial practice to reading a text aloud. Spatial practice understands a place in an embodied way that semiotic decoding cannot:

"The use of the cathedral's monumental space necessarily entails its supplying answers to all the questions that assail anyone who crosses the threshold. For visitors are bound to become aware of their own footsteps, and listen to the noises, the singing; they must breathe the incense-laden air, and plunge into a particular world, that of sin and redemption; they will partake of an ideology; they will contemplate and decipher the symbols around them; and they will thus, on the basis of their own bodies, experience a total being in a total space. [ ... ] In cloister or cathedral, space is measured by the ear. [ . . . ] It is in this way, and at this level, in the non-visible, that bodies find one another". (Lefebvre [1974] 1991, pp. 220-21, 225)

We notice the importance of the body already in this first level of physical or perceived space. Secondly, Lefebvre pointed at the existence of "social space", which is "the space of 'inhabitants' and 'users'", the "dominated—and hence passively experienced—space which the imagination seeks to change and appropriate. It overlays physical space, making symbolic use of its objects" (Lefebvre [1974] 1991, p. 39). Unlike the mental and conceived "representations of space", lived "representational spaces" tend toward non-verbal symbols and signs that simply cannot be deciphered but have to be lived in order to be understood on a deeper, embodied level. Again, the human body places its role on this third level of social or lived space, but also the communitarian 'body' of a society or group of people meaningfully using the space. Hence, Lefebvre broadens mental space to both the individual body (spatial practice) and the collective body (social space).

The intuition at the origin of this study could be reformulated at this point; becoming aware of the reality of space in all its dimensions, especially the ones that imply the body through its spatial (perceived) and social (lived) practice, might indeed be a spiritual and healing experience in the sense of Ulrich's window and of the spatial experience of recovering patients, as referred to above (Uzarewicz 2013; Brichetti 2019, pp. 5-9; Wüthrich 2019).

Likewise, Juhani Pallasmaa denounces the "ocularcentric" architecture of flat, reflecting surfaces of glass and its "contradictory opaque transparency": "The inhumanity of contemporary architecture and cities can be understood as the consequence of the negligence of the body and the senses, and an imbalance in our sensory system" (Pallasmaa 1996, pp. 17-18).

This Finnish architect famously pleads for architecture that stimulates "unconscious peripheral vision", which is more attentive to the acoustical and tactile than to the visual, and allows for a playful chiaroscuro of light and shadows instead of pushing us "out of the space, making us mere spectators" (as does "focused vision", but also what Lefebvre called conceived space, which is only a "representation of space" but no real space) and paralyzing "all imagination" (as does homogenous, bright light) (Pallasmaa 1996, pp. 10, 13, 46). Pallasmaa understands the sense of touch as vision's "subconscious"; our skin is able to read "the texture, weight, density and temperature of matter" (Pallasmaa 1996, p. 56). These are more than mere metaphors; ocularcentric architecture has a weakened sense of materiality, because it obfuscates its patina, texture, and density, squashing solidity and shadows to surface and homogenous clarity without an inch of mystery (so needed for a healthy environment, according to Evans and Mitchell McCoy).

Considering healing, Pallasmaa refers to a walk through a forest as "invigorating and healing due to the constant interaction of all sense modalities" and claims that "standing barefoot on a smoot glacial 
rock by the sea at sunset, and sensing the warmth of the sun-heated stone through one's soles, is an extraordinarily healing experience, making one part of the eternal cycle of nature. One senses the slow breathing of the earth" (Pallasmaa 1996, pp. 41, 58). When architecture is able to engage all the senses as a whole (not just vision), fostering perceived and lived space instead of being merely reduced to the geometry and the measurability of conceived space, it "strengthens the existential experience, one's sense of being in the world, and this is essentially a strengthened experience of self" (Pallasmaa 1996, p. 41). This is precisely what I have defined as healing. According to this architect, enhancing the synaesthetic qualities of an edifice has healing repercussions for the users of that building, in the sense of a renewed consciousness of self. He indeed pleads for recuperating the "emancipating or healing role" of architecture (Pallasmaa 1996, p. 34). Body and space belong together. What is more, by emancipating us from the present and allowing us "to experience the slow, healing flow of time", synaesthetic space contributes to our reconciliation with the world (Pallasmaa 1996, p. 52). Synaesthetic space domesticates limitless 'space' and endless 'time' in concrete, embodied existential metaphors of our being in the world (cf. Pallasmaa 1996, p. 64).

In order to experience the synaesthetic qualities of a building, we have to move through the space and dwell in it. The building needs a human body in order for it to be perceived and lived. The American architect Steven Holl argued that words "cannot substitute for authentic physical and sensory experience" nor "assume the silent intensities of architecture" (Holl 1994, p. 41). Authentic embodied experience can only be found here and now, locally, in a certain place. Photographs and even films cannot reproduce the silent intensities that are revealed in a certain place; "Only the architecture itself offers the tactile sensations of textured stone surfaces and polished wooden pews, the experience of light changing with movement, the smell and resonant sounds of space, the bodily relations of scale and proportion" (Holl 1994, p. 41). All these different, particular sense experiences converge in one synaesthetic "event" or "saturated phenomenon", as opposed to a mere object, in the words of French phenomenologist Jean-Luc Marion (Marion 2010, pp. 37-66). This event might be beyond words but is not inarticulate.

Synaesthetic space is, perhaps, the most invisible and ignored dimension of architecture, although a sensibility for it can be acquired. The French writer Paul Valéry imagines an architect wandering through ancient Rome and asking his interlocutor: "Have you not noticed, when walking through this city, that among its buildings, some are mute, others speak, and lastly, the rare ones, sing?" (Valéry 1924, pp. 105-6) Similarly, Christopher Day suggests: "Although built of matter, architecture need not be dead. It can be life-filled. Its constituent elements and relationships can sing-and the human heart resonate with them" (Day [1990] 2004, p. 6). Hence, we must develop a sensibility to listen to our built environment (Roszak 2020).

In short, buildings are not just volumes and contours that can be seen, but, in the first place, they are space and skin that address our body: "Alongside the prevailing architecture of the eye, there is a haptic architecture of the muscle and the skin" (Pallasmaa 1996, p. 70). Let us now examine a few case studies of recent church architecture that particularly excel in this matter and, therefore, in the healing qualities of its inherent spirituality.

\section{Four Case Studies of Synaesthetic Space}

"Architecture holds the power to inspire and transform our day-to-day existence. The everyday act of pressing a door handle and entering into a light-washed room can become profound when experienced through sensitized consciousness. To see, to feel these physicalities is to become a subject of the senses. As Goethe has remarked, 'One should not seek anything behind the phenomena, they are lessons themselves'". (Holl 1999, p. 14)

As I have stated above, the following case studies only concern church architecture, but they reveal a spiritually healing dimension that, obviously, is not exclusively found in sacred buildings; think, for instance, of John Pawson's recent synaesthetic arrangement of the Feuerle Collection in Berlin (2016), which allows the visitor to slow down and find his or her own pace through the fascinating 
interconnection of stimulation (intensity, variety, complexity, mystery, and novelty), coherence, affordance, control, and restoration (Evans and McCoy 1998).

These case studies will prove to be heterotopias or "counter-sites, a kind of effectively enacted utopia in which the real sites, all the other real sites that can be found within the culture, are simultaneously represented, contested, and inverted" (Foucault [1984] 1986, p. 27). I have chosen them among many others, in the first place simply because I have visited them myself and have, in my own spatial practice, been deeply touched by their "song" (Valéry). That is, they corroborated both intuitions that are the origin of this study: the more multiple senses are engaged (for instance, by not disclosing everything 'at first sight' (allowing mystery and stimulation), but by obliging the visitor to climb up a hill, to go around the building (control), to look for clues (affordance) in order to 'understand' the space (complexity), by surprising her (novelty), by slowing him down (restoration), and by making her aware of the temperature of the air and the texture of the walls (intensity), by carefully playing with light and shadows (mystery and variety) and allowing, thus, for "peripheral vision" (Pallasmaa)), the denser is the synaesthetic space of the building, and the more it is spiritually healing, comforting, soothing, and restorative. Again, the way I will present the following case studies is not aimed at providing general theories about these buildings that would be true for everyone, but rather to demonstrate in situ how the intuitions come true in spatial practice, at least for one visitor who walks through the space for the first time, even though this could change over time (Kaplan and Kaplan 1982; Kieckhefer 2004, p. 7).

Therefore, I will present here what is universally considered as one of the most paradigmatic contemporary churches of all times, Le Corbusier's Pilgrim Chapel at Ronchamp; a more recent example in Holl's St. Ignatius Chapel at Seattle; a building that speaks of reconciliation in more than one sense on the site where once the Berlin wall separated East from West; and the fascinating urbanistic change caused by the construction of a shopping mall for a neogothic church without particular charm. This last example might not be the most obvious one, but it deserves our attention because of the role of people in appropriating a place and enhancing its synaesthetic qualities, in line with what Lefebvre has called "social space" and de Certeau "practiced place".

These four case studies represent different Christian denominations (Roman Catholic, Protestant, Anglican) but, again, the communitarian and liturgical practices can (for now) be left aside when considering their synaesthetic dimensions (even though they must come into account when considering the full range of its social or lived space (this I do in Daelemans 2015a, pp. 251-314)). Moreover, these buildings are intended to welcome visitors of any faith or worldview along with non-religious and secular people who appreciate church buildings for their art historical and architectural qualities. I have chosen the first two case studies because they engage with the human body in multiple ways that oblige the visitor to slow down and to walk through the space in order to fully understand it. That this slowing down and moving through the space has a healing effect upon us personally is the fundamental intuition of this study that I present here tentatively and which every reader will have to discover for him or herself. The last two example case studies engage more explicitly with healing and reconciliation in a more social and historical sense.

For all of the following four case studies, which I present not as 'objects' but as synaesthetic space that comes to the fore in spatial practice (this naturally allows a more poetic and less academic style in its presentation), we might ask how the five architectural features pointed out by Evans and Mitchell McCoy are put into play: stimulation, coherence, affordance, control, and restoration (Evans and McCoy 1998).

Other noteworthy recent chapels that-because of a conscious attention to texture, matter, and light—excel in their synaesthetic dimension are Cunningham's Abbey church (1992) in Dallas; Höger and Hare's St. Thomas von Aquin (1999); Bonilla's Las Nogales School Chapel (2002) in Bogotá; Zumthor's Bruder Klaus Feldkapelle (2007) in Wachendorf; Lintula, Sirola, and Summanen's Kamppi chapel (2012) in Helsinki; Dolinar's Chapel of the Good Shepherd (2015) in Ljubljana; Ochoa's Capilla Cura Brochero (2017) in Villa Cura Brochero in Argentina; and Souto de Moura's Chapel (2018) for the Biennale in 
Venice. The literature often points out their noticeable synaesthetic qualities (Braun 2003; Wöhler 2005; Daelemans 2015a).

\subsection{Le Corbusier's Pilgrim Chapel (1954), Ronchamp, France}

A universally acclaimed and paradigmatic example of synaesthetic space is certainly Le Corbusier's Pilgrim Chapel (1954) at Ronchamp (Jencks 2011, pp. 48-49). Its timeless capacity to intrigue and attract visitors proves that it is truly an architectural "event", which might be spiritual even for people who do not define themselves as such because it seem to address an anonymous, basic, universal, and embodied spirituality. Sitting solitary on a hill, this chapel is a playful sculpture that seems to shape all visitors into pilgrims, as they must climb up the hill and contour the building in order to enter it; the building teasingly changes shapes as one approaches, evoking a ship, a shell, praying hands, a nun's hat, or a bird (variety, mystery, novelty, stimulation).

Inside, the visitor is engulfed in a delightful cave-like feast of shadows, color, and light. When it is hot outside, fresh air on our face cools us down. This space is inciting, as stimulation has to do with "intensity, variety, complexity, mystery and novelty" (Evans and McCoy 1998, p. 85). Dim light attracts the visitor further into its archetypal, motherly womb, where he or she might get a sense of the anonymous, sacred mystery that lingers there, captured between the heavy walls, tacitly pierced by colored light (Söhngen 1961, p. 184; Arnholz 2016, p. 50). The rough texture of the walls, gently caressed by natural light falling from above, invites more than one visitor to hang around in silence (restoration). One needs time to let the atmosphere settle and to adjust one's breathing to that of the space. Like the famous fox of the Little Prince, this building has to be domesticated; space indeed needs time in order to be lived (control). All the senses are engaged; synaesthetic space seems to have been 'scooped out' of some kind of basic, primal matter where humanity meets her origin (Daelemans 2015a, pp. 101-2).

As many visitors and authors have pointed out, the atmosphere here is intrinsically, basically, even 'archetypically' spiritual (even before any liturgy takes place) (Jencks 2011, pp. 48-49; Debuyst 1968, p. 48; Daelemans 2015a, p. 102), even though one's circumstances and expectations highly influence the experience one way or the other (Kieckhefer 2004, p. 7). Unlike Koons's sterile and smooth Balloon sculptures, the skin of this cave-like edifice is thick, heavy, rough, and resistant (Han 2015). Texture and matter address our own skin: the rudimentary and rough spirituality of this building seems to reside in the fact of 'simply' and gently engaging our body. The colored glass evokes playfulness and festivity (unlike the white efficiency of modernism and rationalism). Matter is solidly, voluminously present and firmly rooted, unlike transparent, self-effacing architecture that is only able to exist, almost virtually, in lines and superficies (conceived space). Eschewing overpowering monumentality in which one feels minimized, this sculptural event adopts a human scale (coherence, affordance).

This is architecture at its best, bringing to light the specificity of this art by engaging embodied beings, and all our senses, on a deeply human and universal level; there where we are 'body' (cf. Nietzsche: Leib bin ich), not reducing the experience to the hegemony of vision, but engaging smell, taste, touch, and hearing as well. One becomes aware of one's own body because all the senses are strongly involved; vision was already intrigued, if not satisfied, outside, by the whimsical, archetypal shapes that do not immediately recall the common shape of a known religious building (stimulation). But inside, we have to let go of all familiar ideas about ecclesial architecture and give ourselves over to the synaesthetic space of the architectural "event" (restoration). This building is an instrument for our senses, forcing us to become aware of an existing spirituality and to develop a sensibility for synaesthetic space.

According to the five architectural features defined by Evans and Mitchell McCoy, we could conclude the following. The building seems to present the right balance between stimulation and coherence and, although it is made principally for the Roman Catholic liturgy, on a lonely visit one can choose where to sit and linger (control) and be restored, as the building and its features seem to 
foster restoration. However, the entrance is not easy to find, and this could disorient more than one visitor (affordance).

Unfortunately, its daring shapes and mysterious play of light have been imitated, ad nauseam, in a desperate but unfruitful attempt to recreate its acclaimed 'genius', as if its powerful atmosphere, that is, its synaesthetic space, could be caught in ornamental fragments. In this way, one only poorly reproduces soulless 'conceived space' (Lefebvre). Hence, the strong urge to admire this masterpiece and not to imitate it (Debuyst 1968, p. 48). What really should be adopted (not imitated) is its synaesthetic, organic power.

\subsection{Holl's Chapel of St. Ignatius (1997), Seattle, WA, USA}

One successful recent attempt to create a truly synaesthetic space for similar spiritual purposes is Steven Holl's Chapel of St. Ignatius (1997) at Seattle University. Perhaps the best way to 'understand' this building and the synaesthetic space it creates in our interaction is to listen to the experiences it elicits. One visitor "found herself forced to sit down on first entering the interior, as she was so completely overcome by emotion and memory. The new building acted like a key for her, unlocking a wealth of internal, unspoken language with unanticipated force" (Ivy 1998, p. 15). Another person recalls: "I was like a child—both awestruck and excited to ask my questions. I could not figure out where all the light was coming from and how did all those colors come through clear windows? How was there so much life there?" (Cobb 1999, p. 11).

Whereas, in many contemporary buildings, we are "out of touch with the poetry and unpredictability of the everyday change in the weather" (Holl 1994, p. 83), Holl stages the light in such a masterful way so as to heighten our cosmic awareness. Light-indirect, diffuse, colored, projected against colored walls-spills across the surfaces, creating a playful, shadowy, unique, and festive atmosphere (stimulation). Rather than shiny and smooth, the surfaces themselves are rough, irregular, textured, thick, organic, where human hands left their mark. The walls, the hand-carved wooden furniture, and the hand-blown lamps all remind us of the marvelous synergy between nature and humanity.

The chapel demonstrates Holl's conviction that architecture must be "a series of partial experiences, rather than a totality" (Holl 1994, p. 42), making us move through the space and its different atmospheres, depending on the light, the textures of the walls, and the height of the ceiling: "At every turn, the visitor is invited to listen, touch, inhale, see-to worship the world, and yet transcend it, through the senses" (Dupré 2001, p. 152). As synaesthetic space, this building addresses our body and, therefore, I dare to say, our soul, in the sense that "the Spirit befriends the body" (Rogers 2005, p. 70) and that a human being performs the biological in a spiritual way; that is, experiences "the interpenetration of bios and spirit which is his inmost essence" (Ratzinger [1965] 2014).

Holl suggests that the fundamental 'idea' for this building is not something 'added' to the architectural event but is embedded in the building and embodied by its synaesthetic space: perception without meaning "is ultimately deficient unless intent is articulated" (Holl 1994, p. 41). In this particular case, the 'idea' is taken from the Spiritual Exercises of St. Ignatius of Loyola, where it is said that all divine gifts are "descending from above," leading to Holl's paradigm of "seven bottles of light in a stone box" (Holl 1999).

Similar to Ronchamp, this building helps to 'slow down' by heightening our perception (mystery, novelty, variety). The healing dimension of synaesthetic space is reminding us of our wholeness; that is, that we are embodied and spiritual beings: "The ultimate meaning of any building is beyond architecture; it directs our consciousness back to the world and towards our own sense of self and being. Significant architecture makes us experience ourselves as complete embodied and spiritual beings. In fact, this is the great function of all meaningful art" (Pallasmaa 1996, p. 11). The ability to connect us with our deepest spiritual dimension, through our body, is a fundamental, humanizing experience of architecture (restorative qualities). 
The American philosopher Paul Kidder, who has written a noteworthy analysis of this building in reference to Ignatian spirituality, claims that architecture like this liberates

"by pointing a direction and then withdrawing, by serving, like the Spiritual Exercises themselves, as a guide to personal meditations. In this place we are called to be most truly ourselves and to find ourselves through the love of Christ and the fellowship of community. [ ... ] Christianity is never captured in the systematic overview, the aerial perspective, the blueprint and the floorplan, but unfolds always perspectivally, from our point of view. We know that the fundamental thing is a call that vibrates the air but only becomes sound when heard in our hearts-the call to us to join the feast of poverty, to kneel at the altar and be this odd transformation, the antidote for evil, the body of Christ, the throats of flesh that sing the incarnate word". (Kidder 1999, p. 25)

In other words, for the 'call' to be heard, this call needs, first of all, synaesthetic space to resonate and a responding (individual and communitarian) body to become sound and embodied. Spirituality is not something to be captured in words and ideas but has to be lived and embodied (even when written down in texts, such as the Bible).

Thanks to its strong synaesthetic and thus healing and restorative qualities, and because it displays a spirituality in the broadest sense, not focusing exclusively on its Christian denominational character (although this is obviously present), this Roman Catholic chapel allows for people of different worldviews to feel, in principle, at home in this space, simply because their body (perceived space) is addressed even before their mind (conceived space), without monopolizing the perceived space with representations and verbal signs of conceived space that can only be interpreted in one exclusive way (Holl 1999; Daelemans 2015a, pp. 174-84). This is so because synaesthetic space is spiritual in a broad and anonymous sense (perceived space), even before the Transcendent is named (this naming would be from the order of conceived space and of verbal signs that could be deciphered, as well as of social space and of symbols that are liturgically enacted). Considering the multiple triggers and clues that address the body in this chapel, we could speak of a right balance between stimulation and coherence, with attention to affordance and control, and especially allowing, in the first place, for restoration and rest as its primordial aim on the university campus for anyone who has a body. Our time needs welcoming places that remind us of this human need for restoration and peace that is intrinsically healing (Evans and McCoy 1998; Brichetti 2019, p. 6).

\subsection{Reitermann and Sassenroth's Chapel of Reconciliation (2000), Berlin, Germany}

In Berlin, at a wounded site where once an infamous Wall separated East from West, now sits a small chapel in the modest shape of a wooden shed. The Protestant community (Evangelische Versöhnungsgemeinde) decided courageously and creatively not to rebuild the former neogothic church, demolished in 1985, but to offer the wider world a new and contemporary haven of peace and an imaginative place for reconciliation, even when there is no liturgical event taking place (Braun 2003; Daelemans 2015a, pp. 165-74).

In contrast to a wall that separates people and inhibits space, the Chapel of Reconciliation (2000) is an extraordinary meditation on space and stillness (it allows for restoration). For many years after the demolition of the wall, this part of the city showed a humiliating and shameful piece of desolate and restless wasteland. Something had to be done in order to start a process of healing. The community bravely eschewed triumphalism and opted instead for simplicity, fragility, and humility as more sustainable forces of healing and reconciliation. Humanity as a whole has to be reconciled with its wounds, and this modest building is an example of just that, transforming creatively a wounded genius loci into one full of hope, and providing a place for reconciliation, as a symbol and a banner announcing the need for reconciliation on a wounded site.

Instead of the architects' initial choice of steel and glass, the chapel now displays wood and clay, space and air. Indeed, clay evokes both creation and healing (Turner 1969, p. 103). The chapel, with a 
new shape that in itself is a broad welcome to anyone, believer and non-believer alike, invites the visitor to wander slowly over the desolate grounds towards its inner womb, passing first through an impressive open-air ambulatory made of inexpensive wooden lamellas through which flashes of the outer world can be glimpsed (it provides mystery and novelty, combining stimulation with coherence). Indeed, places like this remind us that reconciliation is not a mental activity disconnected from the body; one even might have to engage in a bodily experience in order to be fully reconciled. Reconciliation might be easier when the body is included. It is a fact that this building literally makes room for reconciliation and lays bare different depths of the name, for the demolished church already was called Church of the Reconciliation.

As such, this innocuous "event" (Marion 2010, pp. 37-66), with its porous skin and grainy core, creates a succession of three different spaces; one moves from the vast, exterior, and secular space of empty wasteland through the liminal space (Van Gennep 1960; Turner 1969) of the delightfully intimate walkway (which at the same time serves as cafeteria, foyer, and exhibition space) towards the interior sacred heart of protected intimacy, which invites one to another 'space' of stillness and peace, even more interior and beyond.

This embodied process of reconciliation incorporates the scars of the past (coherence, affordance): The contours of the demolished church are laid out in the ground; the new altar made out of clay, as are the walls, sits on the mensa of the former church; a mutilated remnant of the former church, a neogothic reredos in which Christ lost his face, hangs in an apse, indicating the orientation of the demolished church and imbuing the empty space with "a real sense of centred gravitas" (Richardson 2004, p. 80); an unexploded WWII-bomb can be glimpsed in the ambulatory, uniting as such war, wall, and wasteland; and in the grainy walls of the central core can be found small pieces of the former, demolished church, as precious stones, relics, and "thorn in the flesh" (2Co 12:7) that offer an opportunity to reconcile the wounded present with the past.

The Protestant community that worships here boldly opted for those broken fragments to speak of a greater whole. As such, the whole event of going through this chapel is in itself a profound and healing rite of passage from brokenness and pain to memory and hope. Outside, a sculpture of a man and a woman embracing hints at the efforts of the union between East and West, overcoming all separation. Heroically, at the core of this new beating heart are the wounds of the past (Braun 2003).

Taking the place of both a separating wall and a demolished church, this synaesthetic space that defies the imagination opts for smallness, offering the visitor different spatial experiences (stimulation), coming together in a hearth of peace and quiet (restoration). Subtly, placing the new altar towards the geographical east, it does not bitterly stick to the past, but orients herself daringly to a new future of hope (novelty). Gathering and reorganizing fragments found on site, it offers a palimpsest of lightness and grace on a wounded site of separation and grief.

A small, innocuous bronze crucifix of the Armenian artist Chavarch Kachatrian expresses well what this chapel is about; in loving nearness, Jesus raises his hand in a continuous blessing and invitation to prophetically stand up and work for reconciliation. One might even say that the chapel, choosing resolutely this devastated no-man's land, is a herald of God's relentless and universal message of reconciliation and a symbol of where the Church of the twentieth-first century, represented in this building (although not only the Protestant community that gathers here, but, because of its ecumenical engagement, the Church in its broadest sense, as People of God) must be. It incorporates the wounded past, offering a spacious present for contemplating the future with hope.

The oscillating ambulatory, swaying gently around the grainy core, defies rectilinear ways of defining the sacred and offers surprisingly new vistas when walking around. The texture of the organic materials appeals to our sense of touch. Inside, the soft, organic colors and the diffused light, falling through an ingeniously designed skylight as the only source of natural light, invite one to stillness and contemplation. Here, it is not mere void, but truly "sacred emptiness" that awaits the visitor (Tillich [1962] 1989; Daelemans 2012). 
In short, the overall simplicity of this apparently negligible gesture in a wounded site invites one, in my view, above all to listen with all the senses, physical and spiritual. This deep and contemplative listening is, in itself, restorative and healing, as we have seen (Pallasmaa 1996, pp. 49-51; Evans and McCoy 1998, p. 91). The grainy loam and the simple wood define this synaesthetic space as an invitation to reconcile oneself with one's wounds, one's world, and one's God.

\subsection{St Martin Church and Selfridges (2003), Birmingham, UK}

Another, final example is telling. For decades, right at the city center of Birmingham (UK), an unimpressive church in Gothic Victorian style stood quietly in the shadows of the so-called 'Bullring': an infamous and confusing cluster of car parks, markets, motorways, and dark alleys attracting mostly criminality and dirt.

In 2003, its genius loci changed completely in what is now one of the busiest shopping malls in the UK. What is more, the attractive, futuristic Selfridges building (seemingly not yet from this age, but as commercial entertainment entirely given to this age) paradoxically enhanced the spiritual function of the church (apparently not from this age anymore, but opening a necessary restorative dimension right in the middle of fuzzy contemporary life, in the sense in which Evans and Mitchell McCoy spoke of "restorative qualities" (Evans and McCoy 1998, p. 91)). Their contrast is fascinating and seems complementary (stimulation). Now, the plaza is an essential place-to-be in the commercial heart of the city.

The Anglican parish community responded well to the spiritual needs of the moment and provided a haven of rest for the numerous visitors, weary from shopping and restlessness. Moreover, the uninspiring shape of the old church became surprisingly eloquent and contemporary because of this felicitous, fertile contrast.

This is an example of how the old and apparently stagnant can become new and dynamic again: perhaps something to consider in view of the buildings we currently use. The building environment is often more dynamic than we might think, something to be 'played' by a community, as with a musical instrument. It is only then that a building is truly itself, "lived space" (Lefebvre), "singing" architecture, and neither mute nor speechless (Valéry): "Design doesn't stop when buildings are completed. It is routinely renewed during occupation and adaption" (Day [1990] 2004, p. 14). The question is: do we own the spaces we use? Does the community that worships in a sacred place own the place? Already Evans and Mitchell McCoy, with their term "control", underlined the importance of the space to be flexible in its adaptation (Evans and McCoy 1998, p. 91). Can we, appropriately, speak of communitarian "appropriation" (de Certeau [1980] 1990, p. 148; Lefebvre [1974] 1991)?

Indeed, a building is not a static object but space that must be played as an instrument. Any building should 'sing' the best it can, in resonance and in interaction with its users. The 'building process' does not end with the construction of the building as object. It is only then that the appropriation can start, that a group of people can start to inhabit the building as space and as event (Marion 2010, pp. 37-66). When, over time, the building still seems foreign and empty, one wonders what has gone wrong. Which small interventions can be done in order to improve our common environment?

In short, we must be attentive to all our senses; awareness seems to be already a first step towards healing and wholeness. In this sense, Sternberg is convinced that "we can each, as individuals, do our part. Rather than rushing through our busy days without paying much attention to the spaces around us, we need to carve out a few moments here and there to allow ourselves to be aware of our place in the world and its place inside us" (Sternberg 2009, p. 295).

\section{Conclusions: A Renewed Sensibility}

"Most of us don't go around deliberately touching buildings, yet without thinking about it, we touch them all the time. The textures we walk on or feel with our hands (or eyes) make all the difference between places which are approachable and which aren't: few people prefer a concrete bench or steel table to a wooden one". (Day [1990] 2004, p. 74) 
In this article, I have used the terms healing, spiritual, and synaesthetic space in such a broad sense so as to exclude nobody from the ability to recognize this experience, simply because we are a body (Nietzsche) and, therefore, nobody is illiterate in spatial practice (Volp 1994). I have merely tried to put words upon an intuitive experience of which not much empirical evidence exists in the literature; although, as we have seen, achievements from different disciplines converge in this direction. Even though the results of this study might seem tentative, I hope to have contributed to a fascinating field of experience, which further research might deepen and unfold.

Developing sensitivity for the synaesthetic quality of places will make us aware of natural light, breathing space (the experience of a tiny space can be broadened dramatically by opening a window towards a garden, for instance), local rootedness, and, especially, boundaries: "Often our experience of buildings is not as free-standing objects but of boundaries of space. The quality of this boundary is a major ingredient of the quality the place will have" (Day [1990] 2004, p. 10).

Naturally, this is not a question of mere 'cosmetics.' By only being attentive to materials, texture, colors, light, air, and space (together with stimulation, coherence, affordance, control, and restoration), it is easy to see how synaesthetic space differs from the physical, material space that we can describe and observe from a distance (as an object). Wood, clay, and stone, for instance, breathe differently than steel, concrete, and plastic. Fascists of all times know well how architecture can support or damage physical and spiritual health, keep people down or uplift them and make them proud of their shared humanity. Synaesthetic space is a particularly powerful atmosphere proper to architecture (Böhme 1995, 2006). This power has the characteristic to involve us as in an event (Marion 2010, pp. 37-66).

Why is this dimension spiritually relevant, and why would it influence healing (still, in a broad sense of restoration and reconciliation), not only physically, but as a whole embodied being? Following the research of healthcare specialists and psychologists (Ulrich, Sternberg, Evans and Mitchell McCoy), philosophers and theologians attentive to space (Lefebvre, Böhme, Löw, Wüthrich), and architects sensitive to the multisensory aspects of buildings (Day, Pallasmaa, Zumthor) and by testing their findings in the spatial practice of concrete case studies, we might formulate the following answer: simply because our living body is addressed, in contrast to some abstract elaborations of 'conceived space' (Lefebvre) that have nothing to do with spirituality because they separate us from our embodied materiality. The 'skin' of the building addresses our skin (in stronger or weaker ways). This is also why such a spiritually healing dimension of synaesthetic space is not reserved for buildings with a specific healing or religious purpose.

This synaesthetic dimension is highly specific to architecture in contrast to other arts. Such architectural experience is unlikely to occur when looking at photographs alone or reading this text (unless our architectural sensibility has been exercised). Instead of looking at an "object", we are involved and participate as embodied beings in an "event" (Marion 2010, pp. 37-66). The bodily experience of the architectural event makes us more aware of our embodied self (Pallasmaa 1996; Löw 2001, p. 224) and, as I have claimed from the start, this is already healing, a step to wholeness.

Hence, the first spiritually healing dimension of architecture therefore has nothing or little to do with styles-still so polemical nowadays when church architecture is concerned (Rose 2001; Doorly 2007; McNamara 2009)—but with its capacity to engage our body in a mystagogical and anagogical, that is, inward and uplifting, movement into the mystery of life.

From our case studies, we may conclude that openness to nature (in whatever way) is an essential feature for the spiritually healing dimension of a building (Evans and McCoy 1998, p. 91). Nevertheless, such 'openness' is not reduced to vision (opening a window) but has more to do with how nature enters the space, in the organic texture and material of the walls, for instance, or in bringing in water, air, earth, and light, as in Zumthor's universally acclaimed Bruder Klaus Feldkapelle. Drawing on a suggestive distinction by the American architectural critic Paul Goldberger, I would say that the Swiss architect, instead of proposing a frame around nature or creating a window on nature, "abstracts" these natural elements out of nature so that they sensibly, but without words, engage our being embodied and embedded in the natural world (Goldberger 2010, p. 228; Daelemans 2015b). The point is, it is 
not nature as such that is healing (that might be so, according to Pallasmaa's suggestive examples as quoted above), but rather the combination of nature and architecture, because healing also implies shelter, coherence, control, affordance, and other aspects not found in nature. The miraculous synergy achieved between the building and nature is what is ultimately healing, for it brings into balance the five architectural aspects defined by Evans and Mitchell McCoy: stimulation, coherence, affordance, control, and restoration (Evans and McCoy 1998).

As necessary as Venice could be as a heterotopia for ordinary life, according to the quote above, we could say that all of the examined case studies provide an imaginative, contemporary "heterotopia" (Foucault), where the visitors of more than one faith and worldview could literally come to their senses, bodily and spiritually, which is an experience of healing, restoration, and reconciliation.

Steven Holl claims that "modern commercial existence muddles the question of what is essential. [... ] If the media make us passive receivers of vacuous messages, we must firmly position ourselves as activists of consciousness" (Holl 1994, p. 41). Therefore, we must engage with the environment:

"To open ourselves to perception, we must transcend the mundane urgency of 'things to do.' We must try to access that inner life that reveals the luminous intensity of the world. Only through solitude can we begin to penetrate the secrets around us. An awareness of one's unique existence in space is essential in developing a consciousness of perception". (Holl 1999, p. 14)

In short, people might perhaps get used to anything, but what we keep forgetting is the synaesthetic dimension of the built environment, and its healing effects by bringing us into contact with our cosmic rootedness. This spiritual dimension becomes more and more essential for contemporary church architecture and concerns a sensibility that can be acquired over time by walking through buildings, inhabiting them, and owning them.

Funding: This research received no external funding.

Conflicts of Interest: The author declares no conflict of interest.

\section{References}

Aguirre, Geoffrey K., Eric Zarahn, and Mark D’Esposito. 1998. An area within human ventral cortex sensitive to 'building' stimuli: Evidence and implications. Neuron 21: 373-83. [CrossRef]

Arnholz, Wiebke. 2016. Form und Funktion der modernen Wallfahrtskirche. Marburg: Tectum Verlag.

Bachelard, Gaston. 1971. The Poetics of Reverie. Boston: Beacon Press.

Bergmann, Sigurd. 2009. Theology in Built Environments: Exploring Religion, Architecture, and Design. New Brunswick: Transaction Publishers.

Beuttler, Ulrich. 2010. Gott und Raum: Theologie der Weltgegenwart Gottes. Göttingen: Vandenhoeck \& Ruprecht.

Beyrich, Tilman. 2011. Theosphären: Raum als Thema der Theologie. Leipzig: Evangelische Verlagsanstalt.

Böhme, Gernot. 1995. Atmosphäre: Essays zur neuen Ästhetik. Frankfurt am Main: Suhrkamp.

Böhme, Gernot. 2006. Atmosphären kirchlicher Räume. Artheon-Mitteilungen 24: 26-31.

Braun, Ulrike. 2003. Versöhnungskirche: Kapelle der Versöhnung. Berlin: Evangelische Versöhnungsgemeinde Selbstverlag.

Brichetti, Katharina. 2019. Unterstützung von Spiritual Care durch räumliche Gestaltung von Gesundheitsbauten. Spiritual Care 8: 3-10. [CrossRef]

Casey, Edward. 1993. Getting Back into Place: Toward a Renewed Understanding of the Place-World. Bloomington: Indiana University Press.

Cobb, Gerald. 1999. Foreword. In The Chapel of St. Ignatius. New York: Princeton Architectural Press.

Codinhoto, Ricardo, Patricia Tzortzopoulos, Mike Kagioglou, Ghassan Aouad, and Rachel Cooper. 2009. The impacts of the built environment on health outcomes. Facilities 27: 138-51. [CrossRef]

Conroy, Pat. 1995. Beach Music. New York: Doubleday.

Cooper Marcus, Clare, and Marni Barnes. 1999. Healing Gardens: Therapeutic Benefits and Design Recommendations. New York: John Wiley. 
Daelemans, Bert. 2012. Tillich and the spilled coffee cup: The breakthrough of the Spirit in contemporary church architecture. Bulletin of the North American Paul Tillich Society 38: 35-53.

Daelemans, Bert. 2015a. Spiritus loci: A Theological Method for Contemporary Church Architecture. Leiden-Boston: Brill.

Daelemans, Bert. 2015b. La presenza reale del cosmo in l'architettura contemporanea. In Architettura, Liturgia e Cosmo. Edited by Goffredo Boselli. Magnano: Qiqajon, pp. 177-94.

Daelemans, Bert. 2015c. Contemplar, celebrar, cuidar. Revisitar la sacramentalidad del mundo. In Cuidar de la Tierra, Cuidar de los Pobres. Laudato si' Desde la Teología y con la Ciencia. Edited by Enrique Sanz Giménez-Rico. Santander: Sal Terrae, pp. 87-103.

Day, Christopher. 2004. Places of the Soul: Architecture and Environmental Design as a Healing Art. Oxford: Architectural Press. First published 1990.

de Certeau, Michel. 1990. Pratiques d'espace. In L'invention du Quotidien 1. Arts de Faire. Paris: Gallimard, pp. 137-91. First published 1980.

Debuyst, Frédéric. 1968. Modern Architecture and Christian Celebration. London: Lutterworth.

Doorly, Moyra. 2007. No Place for God: The Denial of the Transcendent in Modern Church Architecture. San Francisco: Ignatius Press.

Dupré, Judith. 2001. Churches. New York: HarperCollins.

Epstein, Russell A., Whitney E. Parker, and Alana M. Feiler. 2007. Where am I now? Distinct roles for parahippocampal and retrosplenial cortices in place recognition. Journal of Neuroscience 27: 6141-49. [CrossRef] [PubMed]

Evans, Gary W., and Janetta Mitchell McCoy. 1998. When buildings don't work. The role of architecture in human health. Journal of Environmental Psychology 18: 85-94. [CrossRef]

Foucault, Michel. 1986. Of other spaces. Diacritics 16: 22-27. First published 1984. [CrossRef]

Frampton, Kenneth. 2002. Corporeal experience in the architecture of Tadao Ando. In Body and Building: Essays on the Changing Relation between Body and Architecture. Edited by G. Dodds and R. Tavernor. Cambridge: MIT Press, pp. 304-18.

Frick, Eckhard. 2007. Sich Heilen Lassen: Eine Spirituelle und Psychoanalytische Reflexion. Würzburg: Echter.

Frick, Eckhard, and Lydia Maidl, eds. 2019. Spiritual Care 8/1. Spirituelle Räume. Berlin: Walter de Gruyter.

Goldberger, Paul. 2010. Epilogue: On the relevance of sacred architecture today. In Constructing the Ineffable: Contemporary Sacred Architecture. Edited by Karla Cavarra Britton. New Haven: Yale University Press, pp. 222-31.

Hall, Edward T. 1969. The Hidden Dimension. New York: Doubleday.

Han, Byung-Chul. 2015. Die Errettung des Schönen. Frankfurt: Fischer.

Handy, Susan L., Marlon G. Boarnet, Reid Ewing, and Richard E. Killingsworth. 2002. How the built environment affects physical activity: Views from urban planning. American Journal of Preventive Medicine 23: 64-73. [CrossRef]

Heathcote, Edwin, and Laura Moffat. 2007. Contemporary Church Architecture. Chichester: Wiley-Academy.

Holl, Steven. 1994. Questions of perception-Phenomenology of architecture. In Questions of Perception: Phenomenology of Architecture. Edited by Steven Holl, Juhani Pallasmaa and Alberto Pérez-Gómez. Tokyo: A+U, pp. 39-120.

Holl, Steven. 1999. A gathering of different lights. In The Chapel of St. Ignatius. New York: Princeton Architectural Press, pp. 14-29.

Huisman, Emelieke, Ernesto Morales, Joost van Hoof, and Helianthe S. Kort. 2012. Healing environment: A review of the impact of physical environmental factors on users. Building and Environment 58: 70-80. [CrossRef]

Ivy, Robert A. 1998. Editorial: Building Sanctuary. Architectural Record 186: 15.

Jencks, Charles. 2011. The Story of Post-Modernism: Five Decades of the Ironic, Iconic, and Critical in Architecture. New York: John Wiley \& Sons.

Kaplan, Stephen, and Rachel Kaplan. 1982. Cognition and Environment. New York: Praeger.

Kidder, Paul. 1999. Modern Architecture and Ignatian Vision. Lonergan Workshop 15: 13-25. [CrossRef]

Kieckhefer, Richard. 2004. Theology in Stone: Church Architecture from Byzantium to Berkeley. Oxford: Oxford University Press.

Lefebvre, Henri. 1991. The Production of Space. Malden: Blackwell. First published 1974.

López Arias, Fernando. 2018. Proyectar el Espacio Sagrado: Qué es y Cómo se Construye una Iglesia. Pamplona: Eunsa. 
Löw, Martina. 2001. Raumsoziologie. Frankfurt am Main: Suhrkamp Verlag.

Macmillan, Sebastian. 2004. Designing Better Buildings: Quality and Value in the Built Environment. London and New York: Taylor \& Francis.

Marion, Jean-Luc. 2010. De Surcroît: Études sur les Phénomènes Saturés. Paris: Presses Universitaires de France.

McNamara, Denis. 2009. Catholic Church Architecture and the Spirit of the Liturgy. Mundelein: Hillenbrand Books. Norberg-Schulz, Christian. 1980. Genius Loci: Towards a Phenomenology of Architecture. London: Academy.

Pallasmaa, Juhani. 1996. The Eyes of the Skin: Architecture and the Senses. London: Academy.

Ratzinger, Joseph. 2014. Die sakramentale Begründung christlicher Existenz. In Joseph Ratzinger, Gesammelte Schriften 11. Theologie der Liturgie. Edited by Gerhard L. Müller. Freiburg-Basel-Wien: Herder, pp. 197-214. First published 1965.

Richardson, Phyllis. 2004. New Sacred Architecture. London: Laurence King Publishing.

Rogers, Eugene E. 2005. After the Spirit: A Constructive Pneumatology from Resources Outside the Modern West. Grand Rapids: Eerdmans.

Rose, Michael. 2001. Ugly as Sin: Why They Changed Our Churches from Sacred Places to Meeting Spaces and How We Can Change Them Back Again. Omaha, NE: Sophia Institute Press.

Roszak, Piotr. 2020. Mute Sacrum. Faith and its Relation to Heritage on Camino de Santiago. Religions 11: 70. [CrossRef]

Schloeder, Steven J. 1998. Architecture in Communion: Implementing the Second Vatican Council through Liturgy and Architecture. San Francisco: Ignatius Press.

Schmemann, Alexander. 1973. For the Life of the World: Sacraments and Orthodoxy. Crestwood: St. Vladimir's Seminary Press.

Sigrist, Christoph. 2019. Heilende Räume: Diakonische (Ein)Richtung für Spiritual Care. Grundlagen, Perspektiven, Erfahrungen. Spiritual Care 8: 21-30. [CrossRef]

Söhngen, Oskar. 1961. Die Wallfahrtskirche von Ronchamp: Zum Problem des Sakralen im modernen Kirchenbau. In Reich Gottes und Wirklichkeit: Festgabe für Alfred Dedo Müller zum 70. Geburtstag. Berlin: Evangelische Verlagsanstalt, pp. 176-87.

Soja, Edward. 1996. Thirdspace: Journeys to Los Angeles and Other Real and Imagined Spaces. Oxford: Blackwell.

Sternberg, Esther M. 2009. Healing Spaces. The Science of Place and Well-Being. Cambridge: Belknap Harvard University Press.

Tillich, Paul. 1989. Contemporary Protestant Architecture. In On Art and Architecture. Edited by John and Jane Dillenberger. New York: Crossroad, pp. 214-20. First published 1962.

Tsekleves, Emmanuel, and Rachel Cooper. 2016. Design for Health. Abingdon: Routledge.

Tuan, Yi-Fu. 1977. Space and Place: The Perspective of Experience. Minneapolis: University of Minnesota Press.

Turner, Victor. 1969. The Ritual Process. Chicago: Aldine Publishing Company.

Tzortzopoulos, Patricia, Ricardo Codinhoto, Mike Kagioglou, John Rooke, and Lauri Koskela. 2009. The gaps between healthcare service and building design: A state of the art review. Ambiente Construido 9: 37-49.

Ulrich, Roger S. 1984. View through a window may influence recovery from surgery. Science 224: 420-21. [CrossRef]

Ulrich, Roger S. 2006. Evidence-based health-care architecture. Lancet 368: 38-39. [CrossRef]

Ulrich, Roger, Xiaobo Quan, Craig Zimring, Anjali Joseph, and Ruchi Choudhary. 2004. The Role of the Physical Environment in the Hospital of the 21st Century: A Once-in-a-Lifetime Opportunity. Concord: The Center for Health Design.

Uzarewicz, Charlotte. 2013. Über die Räumlichkeit des Sterbens. In Zugang zum Menschen: Angewandte Philosophie in zehn Berufsfeldern. Edited by Heinz Becker. Freiburg-München: Karl Alber Verlag, pp. 201-23.

Valéry, Paul. 1924. Eupalinos, ou L'architecte. Paris: Gallimard.

Van Gennep, Arnold. 1960. The Rites of Passage. Chicago: University of Chicago.

Volp, Rainer. 1994. Space as text: The problem of hermeneutics in church architecture. Studia Liturgica 24: 168-77. [CrossRef]

Wöhler, Till. 2005. Neue Architektur: Sakralbauten. Berlin: Braun.

Wüthrich, Matthias D. 2010. Raumtheoretische Erwägungen zum Kirchenraum. In Kirchen Macht Raum: Beiträge zu Einer Kontroversen Debatte. Edited by Christoph Sigrist. Zürich: Theologischer Verlag, pp. 71-88.

Wüthrich, Matthias D. 2015. Raum Gottes: Ein Systematisch-Theologischer Versuch, Raum zu Denken. Göttingen: Vandenhoeck \& Ruprecht. 
Wüthrich, Matthias D. 2019. Spirituelle Räume: Ein Vorschlag zur Konzeptionalisierung von "Raum" im Kontext von Spiritual Care. Spiritual Care 8: 31-38. [CrossRef]

Zumthor, Peter. 2010. Thinking Architecture. Basel: Birkhäuser.

Publisher's Note: MDPI stays neutral with regard to jurisdictional claims in published maps and institutional affiliations.

(C) 2020 by the author. Licensee MDPI, Basel, Switzerland. This article is an open access article distributed under the terms and conditions of the Creative Commons Attribution (CC BY) license (http://creativecommons.org/licenses/by/4.0/). 